\title{
ZAMĚSTNANECKÉ BENEFITY - (NE)RUTINNÍ POSKYTOVÁNÍ V KONTEXTU SOCIÁLNÍ POLITIKY PODNIKU
}

\author{
Radim Řihák, Vojtěch Malátek
}

\section{Klíčová slova:}

Podnik, zaměstnanec, zaměstnanecký benefit, postoj k práci, sociální politika podniku, teze disertační práce, předvýzkum, respondent.

\section{Key words:}

Enterprise, employee, employee benefit, attitude to work, corporate social policy, doctoral thesis, pilot survey, respondent.

\begin{abstract}
Abstrakt
Článek se svým obsahem zaměřuje na problematiku odměňování pracovníků v podnicích s dưrazem na sociální politiku a benefitní odměňování. Poukazuje na důležitost propojení procesů hodnocení a odměňování v podnicích a to nejen ve vztahu $\mathrm{k}$ benefitnímu odměňování a účinné, racionální sociální politice, jež jsou předpokladem pro vytváření příznivého pracovního prostředí, vyšší angažovanost a loajalitu pracovníků. V článku, který vychází z tezí disertační práce doktoranda a realizovaného pilotního průzkumu (metoda dotazování, technika dotazníku), je poukazováno na potřebu nerutinního poskytování zaměstnaneckých benefitů a vhodnost podmínit čerpání některých z nich splněním stanovených kritérií zohledňujících pracovníkův postoj k práci, přičemž pozitivní stanovisko k modifikovanému přístupu k zaměstnaneckým výhodám vzešlo také z výsledků realizovaného předvýzkumu.
\end{abstract}

\begin{abstract}
The article focuses on the issue of remuneration of employees in enterprises with an emphasis on social policy of rewarding and benefit remuneration. The article points out the importance of linking employee appraisal and remuneration processes in enterprises, and that not only in relation to benefit remuneration and effective and efficient social policy which are a prerequisite for creating a favourable working environment, higher commitment and loyalty of employees. In the article, which is based on the doctoral thesis and the conducted survey (the method of questioning - the questionnaire technique), there is accented the need of providing benefits to non-routine and suitability to draw some benefits conditional upon specified criteria that take into account worker's attitude to work. Positive opinion about the benefits of the modified approach has arisen also from the results of the pilot survey.
\end{abstract}

\section{Úvod}

Záměrem většiny společností, at' se jedná o malý, střední či velký podnik, je snaha o budování dobrého jména, resp. příznivé image organizace, a to především směrem navenek - tedy co nejblíže k (potenciálním) zákazníkům - a také ve vztahu ke svým zaměstnancům. Je třeba mít na paměti skutečnost, jak uvádí autoři Vodák a Kucharčíková, že ,pokud chce podnik dlouhodobě prosperovat, je v jeho vlastním zájmu vynaložit úsili k efektivnímu využívání potřebných vstupĩ včetně lidského kapitálu. "l V současném turbulentním a konkurencí silně ovlivněném tržním prostředí je pozitivní vnímání daného podnikatelského subjektu jedním

\footnotetext{
${ }^{1}$ VODÁK, J., KUCHARČÍKOVÁ, A. Efektivní vzdělávání zaměstnanců. 2011, s. 13.
} 
z důležitých faktorů jeho budoucího úspěchu, k čemuž zaměstnanci nesporně přispívají. Nejde jen o vytvoření co nejvyššího zisku za určité období, udržení si konkurenceschopnosti v rámci odvětvové působnosti, či dosažení vytýčeného podílu na domácích nebo zahraničních trzích, nýbrž je nutné se s plnou vážností zabývat potřebami, požadavky a představami svých vlastních pracovníků ve všech oblastech vzájemné působnosti, jakožto zaměstnavatele a zaměstnance ${ }^{2}$. Jedná se bezesporu i o působnost v oblasti sociální politiky podniku, u zaměstnaneckých výhod, dle názoru autorů tohoto článku, ovšem s nutností dílčí souvislosti zohledněním - pracovníkova zaujímaného postoje k práci. Vzájemnou snahou zaměstnavatele i pracovníka by mělo být vytváření flexibilních, spravedlivých, př́iznivých podmínek a pozitivního pracovního prostředí, $\mathrm{k}$ němuž uvědomělá realizace sociální politiky zajisté přispívá.

Hlavním záměrem je $\mathrm{v}$ rámci předkládaného textu poukázat na důležitost a významnost propojení procesů hodnocení a odměňování pracovníků $\mathrm{v}$ podnicích, včetně systému benefitního odměňování a na potřebu uplatňování racionální sociální politiky v podniku, co do struktury portfolia poskytovaných služeb a benefitů pro zaměstnance, $\mathrm{v}$ součinnosti se záměrem podmínit čerpání určitých benefitů splněním stanovených kritérií pracovníkem zohledňujících jeho postoj $\mathrm{k}$ práci. $\mathrm{V}$ této souvislosti článek přináší také dílčí výsledky pilotáže realizované metodou dotazování (technikou dotazníku) v rámci předvýzkumu při zpracování tezí disertační práce spoluautora ${ }^{3}$ zabývající se předmětnou problematikou v oblasti HR. Záměrem příspěvku tedy není detailní identifikace, specifikace, či určení rozdílností, způsobů a forem poskytování benefitů. Účelem taktéž není analyzování jednotlivých benefitních položek co do míry jejich nákladové výhodnosti ve vztahu k odvodovým povinnostem zaměstnavatele či pracovníka. V př́íspěvku se autoři zmiňují o vlivu a významu sociální politiky na vzájemné vztahy (působnost zaměstnance a zaměstnavatele); stejně jako na vhodnost pozbytí mnohdy až rutinního (automatického) čerpání benefitů pracovníkem, přičemž záměrem spoluautora je v rámci jednoho z dílčích cílů zpracovávané disertační práce navrhnout metodiku benefitního odměňování pracovníka zohledňující jeho postoj k práci.

\section{Sociální politika, jakožto důležitý element personální strategie podniku}

$\mathrm{V}$ prostředí neustálých změn a stále navyšujících se požadavkủ na flexibilitu pracovníka, na jeho odolnost vůči stresu, větší aktivitu a samostatnost v pracovním procesu se mění i struktury zavedených podnikových procesů a postupů se snahou jejich neustálého zefektivňování a se záměrem zvyšování konkurenceschopnosti a tržní hodnoty podniku ${ }^{4}$. Oproti prvním porevolučním rokům z konce minulého století (po roce 1989), kdy bylo běžné,

\footnotetext{
${ }^{2}$ Autoři příspěvku pojímají v textu užívané termíny „podnik“, „firma“, „,společnost“ za synonyma, a to s plným vědomím jejich dílčích odlišností z pohledu legislativy a dalších specifik. Důvodem tohoto přístupu jsou především skutečnosti, že někteří autoři, at' už domácí či zahraniční, v rámci svých publikačních výstupů a popisovaných širších souvislostí zmiňované termíny ztotožňují. Po doktorandově uvážení podpořeném konzultacemi se školitelem doc. Malátkem, autoři zaujali stejný postoj u (v textu uváděných) pojmů „pracovník“, „Zaměstnanec“. V těchto případech se hovoří taktéž o synonymech, přičemž pracovník (zaměstnanec) je chápán za jedince, který je v pracovně právním vztahu se zaměstnavatelem bez ohledu na to, zda se jedná o „kmenového“ zaměstnance, či jedince vykonávajícího práci na základě uzavřené Dohody o provedení práce, Dohody o pracovní činnosti, případně vztahu upraveného na základě jiného právního aktu.

${ }^{3}$ Téma disertační práce Ing. Radima Řiháka zní: Odměňování pracovníků ve středních a velkých podnicích. Text předkládaného článku vychází z části tezí disertační práce doktoranda a zahrnuje další uvedené zdroje. Vědeckovýzkumná činnost posluchače doktorského studia byla podpořena Moravskoslezským krajem v rámci programu „Podpora vědy a výzkumu v Moravskoslezském kraji“ pro rok 2012.

${ }^{4}$ Zvyšování konkurenceschopnosti podniku spolu se záměrem managementu podniku na utváření vyšší tržní hodnoty podniku by měly být spolu s tvorbou image společnosti jedněmi z klíčových přístupů managementu každého (nejen středního a velkého) podniku.
} 
že délka setrvání zaměstnance v pracovním vztahu u jedné společnosti směřovala $\mathrm{k}$ deseti letům a déle, je dnes situace podstatně složitější a značně odlišná.

\subsection{Provázanost hodnocení a odměňování pracovníků v kontextu sociální politiky}

Zainteresovanost na budování a dosažení pozitivních vzájemných vztahů a příznivého pracovního prostředí závisí v nemalé mîre na představitelích managementu jednotlivých podniků, mimo jiné na realizované sociální politice, resp. na tom, jak a zda se členové managementu ,zajimaji o to, co by se mělo udělat pro dosažení trvale vysoké úrovně výkonu lidí. Znamená to věnovat zvýšenou pozornost nejvhodnějším způsobům motivování lidí pomocí nástrojů, jako jsou různé stimuly, odměny, vedení lidí a - co je nejdůležitější - práce, kterou vykonávají, a podmínky vorganizaci, za nichž tuto práci vykonávají. Cílem je vytvářet a rozvijet motivačni procesy a pracovní prostředí, které napomohou tomu, aby jednotliví pracovníci dosahovali výsledkù odpovídajících očekávání managementu. " 5 Nejen výše zmíněné se odvíjí od úrovně strategického řízení lidských zdrojů a uplatňované sociální politiky $\mathrm{v}$ podniku.

\subsubsection{Hodnocení a odměňování pracovníků}

$\mathrm{Z}$ pohledu personální strategie podniku je racionální rozpracovat a koncipovat substrategie (dílčí strategie) hodnocení pracovníků a odměňování pracovníků, včetně strategie benefitního odměňování, a to v souladu se strategií podniku. Vyvstávají totiž také prrípady, kdy se hodnocení pracovníků $\mathrm{v}$ pracovně právním vztahu zaměstnance a zaměstnavatele v podnicích nesetkává se vzájemným pochopením. „Z mnoha stran lze slyšet, že hodnocení nefunguje a je považováno za nutné zlo, které nepřináší patřičný efekt. Hodnocení patři k nejméně oblíbeným aktivitám jak na straně nadřizených, tak i jejich podřizených. " 6 Je nutné, nejen dle autorů př́pěvku, $\mathrm{k}$ hodnocení pracovníka přistupovat uvědoměle a s plnou vážností, především pak v souvislosti s faktem vynakládání značného obnosu finančních prostředků v rámci procesu odměňování, a to na každého z pracovníků. Provázanost systémů hodnocení, odměňování, včetně systému benefitního odměňování (systému často opomíjeného, prostřednictvím něhož jsou alokovány nemalé finanční prostředky ovšem mnohdy s nevýrazným dopadem, resp. neuspokojivým efektem a zpětnou vazbou pro management podniku) je z pohledu jejich vzájemné existence rozhodující. Pracovníci daného podniku jsou angažováni ve své práci, když mají zájem na tom, co dělají - tedy tehdy, když je jejich práce naplňuje. Vliv na míru angažovanosti a oddanosti, resp. loajality, pracovníka k podniku může mít mimo jiné uplatňovaná sociální politika podniku, konkrétně pak poskytované zaměstnanecké benefity, přesněji řečeno komplexní systém benefitního odměňování pracovníků.

Řada autorů odborných příspěvků a studií se zmiňuje o trendech v HR oblasti, přičemž jak uvádí také Palata, diskuze a následné kroky by měly směřovat prioritně k tomu, jak systémy hodnocení a odměňování pracovníků nastavit a přizpůsobit novým prioritám v oblasti HR za situace omezených finančních rozpočtů podniků, a sice přistupovat ke směřování procesů odměňování od přístupu „Best Practise“ $\mathrm{k}$ „Best Fit“. ${ }^{7} \mathrm{Je}$ třeba podotknout, že systém odměňování by měl být schopen diferencovat výkonné zaměstnance od nevýkonných; zohlednit pracovníky s různou úrovní požadovaných kompetencí; diferencovat pracovníky na základě jejich strategické významnosti pro podnik, jejich tržní hodnoty na trhu práce, k čemuž přispívá vhodně nastavený a úspěšně implementovaný systém benefitního odměňování. Pilařová poukazuje na situace, kdy „některé organizace bez ohledu na výsledky hodnocení

\footnotetext{
${ }^{5}$ ARMSTRONG, M. Řízení lidských zdrojů. 2002, s. 159.

${ }^{6}$ HRONÍK, F. Hodnocení pracovníků. 2006, s. 16.

${ }^{7}$ PALATA, K. Trendy v odměňování. HRM - Human Resources Management, březen - duben 2011, s 14.
} 
prováději každoročně plošné navýšení mezd, obvykle ve výši inflace, " 8 přičemž tato skutečnost často vede k problémům, kdy daný pracovník, resp. pracovní pozice je bud'to přeplácena nebo naopak nedoceňována; dochází k nedostatečné diferenciaci pracovníků mezi těmi s vysokou a nízkou úrovní požadovaných kompetencí a $\mathrm{k}$ malé pružnosti systému odměňování při změně tržní hodnoty konkrétních pracovních pozic. Nastávají také případy, kdy podniky navyšují svým zaměstnancům pevnou složku mzdy v závislosti na počtu odpracovaných let, a to např́íklad v případech, kdy tento faktor dlouholetého působení ve společnosti nemají „ošetřen“" ${ }^{\text {}} \mathrm{v}$ rámci systému benefitního odměňování, což vyvolává otázku míry důležitosti a role (pozice) benefitního odměňování ve vnímání představitelů vedení dané společnosti, potažmo jejich zaměstnanců. Autoři př́spěvku poukazují na fakt, který může být vzhledem $\mathrm{k}$ nedůslednosti představitelů managementu některých podniků opomíjen a sice, že od systému odměňování a také od úrovně propracovanosti systému benefitního odměňování, způsobu poskytování zaměstnaneckých výhod se vurčité míře odvíjí také: přístup a důslednost zaměstnance $\mathrm{k}$ plnění svých pracovních povinností, svěřenému pracovnímu úkolu, odvedenému výkonu, míra jeho angažovanosti a v nepřímé souvislosti také úroveň motivace související s odvedeným pracovním výkonem. Je možno polemizovat o míre vlivu, jaký mají mezilidské pracovní vztahy a vnitropodnikové prostředí na míru spokojenosti a loajality pracovníků k podniku samotnému.

\subsection{Sociální politika - podstatná součást personální strategie podniku}

Je třeba podotknout, že sociální politika není v současnosti jednoznačně definována, všeobecně zažitá definice $\mathrm{v}$ podstatě neexistuje. Nejpreferovanější ve vztahu $\mathrm{k}$ sociální politice je konotace snah bezprostředně směřujících ke zdokonalování životních podmínek lidí. Na základě uvedeného lze souhlasit s názorem autora Tomeše, že sociální politika je soustavné, cílevědomé úsilí sociálních subjektů o změnu, nebo udržení sociálního systému. ${ }^{10}$ Mimo jiné to znamená, že taková sociální politika musí mít svůj cíl a neustále - soustavně se musí přizpůsobovat měnícím se podmínkám společnosti.

Změny (zejména $\mathrm{v}$ oblasti financování podniků), které vyvstaly $\mathrm{v}$ období hospodářského útlumu let nedávno minulých, nasměrovaly řadu společností k přristoupení na opatření, která spočívala především v redukci počtu svých pracovníků, ale tak realizované péče o pracovníky; v zeštíhlení portfolia zaměstnaneckých benefitů a $\mathrm{v}$ redukci poskytovaných služeb v rámci sociální politiky podniku. Tímto řada z nich docílila značných finančních úspor. Je však třeba si položit otázku: Nakolik racionální by bylo realizování dalších opatření majících za cíl v oblasti odměňování zaměstnanců opětovné redukce (spočívající ve snižování či stagnaci výše mezd, úspory v sociální politice podniku včetně redukce portfolia zaměstnaneckých benefitů), a to především $\mathrm{z}$ důvodu neustálé hrozby pokračujícího hospodářského útlumu, vlivu konkurence a s tím souvisejícího ne/úspěchu $\mathrm{v}$ boji o kvalifikovanou pracovní sílu - o potenciálního uchazeče na volné ${ }^{11}$ pracovní místo? Takováto další neuvážená, restriktivní opatření v oblasti odměňování a v neposlední řadě také v oblasti sociální politiky by mohla vyvolat negativní dopady mající souvislost především s ukončením pracovních poměrů některých klíčových, kvalifikovaných pracovníků, tzn. vyšší

\footnotetext{
${ }^{8}$ PILAŘOVÁ, I. Jak efektivně hodnotit zaměstnance a zvyšovat jejich výkonnost, 2008, s. 63.

${ }^{9}$ Případně formou (přiznáním) jednorázové odměny, která je v mnoha případech ztotožňována (svou povahou, důvodem udělení), kdy je možné, „mzdově zvýhodnit zaměstnance za délku pracovního poměru u organizace“ tedy za odpracované roky $\mathrm{v}$ daném podniku ve snaze posílit stabilizaci a loajalitu k zaměstnavateli. DVOŘÁKOVÁ, Z. a kol. Management lidských zdroju․ 2007, s. 337.

${ }^{10}$ TOMEŠ, I. Sociální politika : teorie a mezinárodní zkušenost. 1996, s. 19.

${ }^{11}$ Skutečnost, že volná pracovní síla - resp. značný počet nezaměstnaných - představují v obecné rovině pro podniky možný potenciál, je možné chápat jako reálné tvrzení, ovšem ne vždy znamená značný počet nezaměstnaných kvalifikovanou (podnikem požadovanou) pracovní sílu.
} 
fluktuací zaměstnanců a s tím vyvstalou následnou nutnost vynakládat značné finanční prostředky na zajištění nových pracovníků potřebných v pracovním procesu daného podniku.

Postupem doby si představitelé vedení podniků stále více uvědomují potřebu investování do lidského kapitálu, a to i v současné turbulentní době složitých změn, jelikož zdroji invencí a realizátory inovací jsou kvalifikovaní pracovníci. V patřičné mîre důležitosti věnovat pozornost sociální politice podniku (v součinnosti se systémy hodnocení a odměňování), zaměřující se ve své podstatě na péči o zaměstnance, jejich sociální rozvoj a poskytování zaměstnaneckých benefitů. ${ }^{12}$ Sociální rozvoj ${ }^{13}$ doznal, v souvislosti s péčí o pracovníky a systémy poskytování zaměstnaneckých výhod v podnicích především v České republice (za posledních 15 let) výrazných obměn a stal se důležitou integrální součástí personální politiky zaměstnavatelů vůči svým zaměstnancům, prričemž po nastolení tržního systému v naší zemi se sociální rozvoj výrazně promítá do charakteru podnikové kultury. Jeho rozvoj můžeme z části přisuzovat také faktu neustále se zvyšujících nároků na pracovníky v mnoha profesích, jež jsou př́činou výskytu potíží zdravotního (především psychického) rázu, mající vliv jak na jedince samotného, tak často i na jeho rodinný život. V přímých souvislostech s faktem nedostatku času je pracovník vystavován situaci, kdy jen obtížně zvládá slad’ování pracovního a rodinného života, přičemž důsledkem jsou vyvstalé konflikty na pracovišti, problémy v rodinném životě, zvýšená absence v docházce do práce, stejně jako hrozba syndromu vyhoření, snazší propadnutí kouření či užívání návykových látek. Je třeba mít na paměti, že tyto problémy mohou mít značný negativní dopad taktéž na zaměstnavatele a v případě výskytu problémů u více pracovníků mohou působit nemalé komplikace.

Výše uvedené doprovází fakt, že náplní sociální politiky uplatňované v konkrétním podniku by měla být právě snaha o vyváženost pracovního a osobního života každého zaměstnance. ${ }^{14}$ Sociální rozvoj zaměstnanců a zaměstnanecké benefity nevyjímaje dosahují značného významu jak pro zaměstnance, tak pro podnik:

Význam pro zaměstnavatele se jeví především v následujícím:

- „prosadit se při stále rostoucí konkurenci na trhu práce kvalifikovaných pracovníků při jejich získávání a výběru;

- nutnost stabilizovat kvalifikované a výkonné zaměstnance a snižit negativní dopady

fluktuace;

- zvýšit spokojenost zaměstnanců, zlepšit pracovní klima a výkon;

- možnost zvyšovat celkový příjem zaměstnance (mimomzdové odměňování) a tím být úspěšnější v konkurenci a prí utváření své image;

- náklady na některé sociální služby a zaměstnanecké výhody jsou daňově uznatelné a osvobozené od odvodi na sociální a zdravotní pojištění;

- možnost ovlivňovat zaměstnance. " 15

Významným pro zaměstnance se jeví následující:

- sociální služby a zaměstnanecké výhody jsou snadno dostupné;

\footnotetext{
${ }^{12}$ DVOŘÁKOVÁ, Z. a kol. Management lidských zdrojů. 2007, s. 365.

${ }^{13}$ Pod termínem „,sociální rozvoj organizace (podniku)“ jsou chápána opatření směřující k rozvoji zaměstnanců organizace, resp. jde o „souhrn specifických opatření zaměrených na vytváření př́znivých vnitřních a vnějších podmínek uspokojování sociálních potřeb zaměstnanců, tj. materiálních i nemateriálních. " DVOŘÁKOVÁ, Z. a kol. Management lidských zdrojü. 2007, s. 365.

${ }^{14}$ Podrobněji se těmito souvislostmi v posledních letech stále více zabývá oblast work-life balance, přičemž k výraznějšímu zájmu o ni došlo ve světě především v druhé polovině 80 . let 20. století, kdy organizace začaly měnit svou personální politiku a přístup k benefitům. Termín work-life balance je nejčastěji v odborné literatuře překládán jako „rovnováha mezi prací a osobním/soukromým životem“.

${ }^{15}$ DVOŘÁKOVÁ, Z. a kol. Management lidských zdrojů. 2007, s. 365 - 366.
} 
- neprrímé odměňování zvyšuje příjem zaměstnance, ale zpravidla nezvyšuje daň z př́ijmu fyzických osob;

- produkty či služby poskytované $v$ rámci benefitního odměňování snižují výdaje pracovníka(ů) na tyto produkty/služby, které by si jinak pořizoval(i) na trhu bez uplatnění benefitního zvýhodnění.

\subsection{Zaměstnanecké benefity}

Z pohledu míry významnosti přikládané zaměstnaneckým výhodám je třeba poukázat na fakt, že jednotliví představitelé, at' už domácí či zahraniční odborné literatury, přisuzují poskytovaným zaměstnaneckým benefitům různou roli (pozici) a míru důležitosti, ve vztahu tohoto elementu k ostatním složkám celkové mzdy zaměstnance. Zaměstnanecké výhody se rozčleňují na základě různých charakteristik a dělení z různých úhlů pohledu. ${ }^{16}$ Jak uvádí Dvořáková, jsou součástí „systému péče o pracovníky i systému odměňování. Pro okoli mohou být tou nejviditelnější součástí personálního řízení. Poskytování určitých zaměstnaneckých výhod má výrazný sociální rozměr a představuje účinné prostředky sociálního rozvoje zaměstnancü. ${ }^{17}$ Pelc konstatuje, že „benefitem je libovolné zvýhodnění vlastních zaměstnancủ zaměstnavatelem ve srovnání se třetími osobami - „nezaměstnanci“, zvýhodnění, jež plyne $v$ souvislosti s výkonem závislé ćinnosti, z důvodu existence této závislé ćinnosti. "18

Jedno z publikovaných členění zaměřené na různou ,intenzitu“ sociálního rozměru charakterrizuje benefity jako:

- „výhody sociální povahy (penzijní pripojištění, životní pojištění hrazené zcela nebo z části organizací, půjčky s ručením za půjčky, jesle a mateřské školky atd.);

- výhody mající vztah kpráci (závodní stravování, výhodnější prodej produkti̊ organizace zaméstnancům, vzdělávání hrazené organizací aj.);

- výhody spojené s postavením v organizaci (automobil, mobil, reprezentační náklady, bezplatné bydlení apod.). ${ }^{19}$

Zaměstnanecké výhody jsou charakteristické dále následujícím:

- „nebývají závislé na zásluhách, jejich rozsah a struktura se často zlepšuje s postavením zaměstnance v organizaci a délkou jeho pracovního poměru;

- neznamenají, že všichni zaměstnanci je vnímají jako výhodu;

- často jsou zaváděny proto, že kopírují trend nebo morální závazky a nejsou podloženy racionální analýzou;

- jakmile jsou zavedeny, je obtížné je zrušit a zaměstnanci je vnímají spíše jako přirozenou součást pracovního vztahu než jako nadstandardní péči;

- dosud nelze předložit jasný důkaz o tom, že benefity pritahují uchazeče o zaměstnání. Je však pravděpodobné, že odrazují zaměstnance, aby ukončili pracovní poměr;

- mohou pozitivně působit na pracovní spokojenost, ale vždy podněcují nespokojenost, jestliže je jejich přiznávání spravováno nesystémově a ledabyle, že to vyvolává pocity nespravedlivosti, obvinění z nadržování nebo favorizování. “20

Jedním z důležitých členění je hledisko „důvodu poskytování“ benefitů, přičemž obecně jsou rozeznávány benefity pro zaměstnavatele povinné, vyžadované zákonem či jinými obecně platnými předpisy (případně zakotvené v kolektivní smlouvě nadpodnikové úrovně); smluvní

\footnotetext{
${ }^{16}$ Smyslem tohoto textu není kompletní výčet členění a charakteristik jednotlivých zaměstnaneckých výhod; byla proto vybrány jen některé z nich.

${ }^{17}$ DVOŘÁKOVÁ, Z. a kol. Management lidských zdrojů. 2007, s. 367.

${ }^{18}$ PELC, V. Zaméstnanecké benefity v roce 2011. 2011, s. 8.

${ }^{19}$ DVOŘ́́KOVÁ, Z. a kol. Management lidských zdrojů. 2007, s. 367.

${ }^{20}$ Tamtéž, s. 339.
} 
benefity zakotvené v kolektivní smlouvě dané firmy; výhody dobrovolné, jež jsou výrazem cílů personální politiky firmy, nejčastěji její snahy o spokojenost zaměstnanců a získání dobré pověsti či posílení pozice podniku na trhu práce. Dalším významným hlediskem je daňová zátěž pro daný benefit. ${ }^{21}$

V podnicích působících v České republice a také v dalších evropských zemích, v nichž se

tržní kapitalismus projevil po roce 1989, se uplatňoval (a v některých př́ípadech stále uplatňuje) přístup preferující plošné poskytování zaměstnaneckých benefitů na úkor flexibilní formy poskytování (např̀. v podobě Cafeteria systému). Přetrvávající oblíbenost v poskytování benefitů na základě plošné nabídky potvrdily také výsledky výzkumu Slezské univerzity v Opavě, realizovaného mezi podniky v Moravskoslezském kraji v roce 2010, kdy: „Výzkum ukázal, že zejména zaměstnavatelé dotazovaní v okrese Ostrava poskytují benefity zaměstnancưm plošně, v malých organizacích je to $50 \%$ zaměstnavatelü, ve středních organizacích je to $52 \%$ zaměstnavatelü a ve velkých organizacích $78 \%$ zaměstnavatelü. Vysoký podíl plošně poskytovaných benefitư byl zaznamenán také v okrese Frýdek-Místek, $v$ malých organizacích je to $67 \%$ zaměstnavatelü, ve středních a velkých organizacích je to $50 \%$ zaměstnavatelů. “22 Jak je z výše uvedeného patrné, jen částečně je poskytování benefitů odvislé od pracovní pozice zaměstnance či od délky působení zaměstnance v podniku.

Obecně zaměstnanecké výhody začaly být v České republice vnímány s vyšší vážností počátkem roku 2001, kdy se některé z finančních produktů staly daňově odečitatelnými položkami, a tudíž začaly být pro řadu zaměstnavatelů zajímavou a výhodnou alternativou jak nabídnout svým pracovníkủm nadstandardní podmínky, které by posílily a upevnily vzájemné vztahy a pozitivně působily na firemní prostředí. Je možné predikovat stále výraznější zastoupení některé z flexibilních forem poskytování zaměstnaneckých benefitů, at' už zmiňovaného Cafeteria systému či pro podnik jiné vhodné kombinace na bázi flexibilního poskytování benefitů. „Trendem let současných a budoucích je individualizovat strukturu př́jmu včetně zaměstnaneckých výhod podle pracovního výkonu a důležitosti zaměstnance, " 23 resp. přizpůsobování struktury zaměstnaneckých výhod individuálním preferencím a potřebám pracovníků, přičemž je možné v následujících letech očekávat četné zavádění různých forem benefitního odměňování založených především na flexibilním čerpání benefitů.

\section{Rutina v poskytování zaměstnaneckých benefitů vs. stanovení kritérií pro jejich čerpání zohledňující pracovníkův postoj $\mathrm{k}$ práci}

V posledních letech se tematikou benefitního odměňování, poskytováním zaměstnaneckých výhod, včetně jejich formy či způsobu čerpání zabývá řada autorů odborných publikací a vědeckých statí, a to jak v teoretické, tak praktické rovině, manažery podniků po celém světě nevyjímaje. Názor na význam benefitů může mít každý z manažerů, potažmo zaměstnanců růžný, či dokonce odlišný. Přirozeně se objeví zastánci současné podoby benefitního odměňování, kteří budou prohlašovat, že péče o pracovníky by měla být ve vnímání zaměstnavatele brána v plném (maximálním) rozsahu, jakožto jeho určitá „povinnost“ vůči svým zaměstnancům a součást realizované sociální politiky podniku.

\footnotetext{
${ }^{21}$ V této souvislosti organizace zvažují, zda a které zaměstnanecké výhody poskytovat. Náklady na poskytování mohou nebo nemusí být pro podnik nákladem daňově uznatelným; podobně jako případ, že benefit může nebo nemusí být osvobozen od daně z prríjmu fyzických osob ze závislé činnosti.

${ }^{22}$ KOLIBOVÁ, H. a kol. Péče o zaméstnance v programech vnitropodnikové sociální politiky v Moravskoslezském kraji. 2010, s. 418.

${ }^{23}$ DVOŘÁKOVÁ, Z. a kol. Management lidských zdrojů. 2007, s. 339.
} 
Řada společností v období hospodářského útlumu váhala se zaváděním nových benefitů, ve většině prrípadů docházelo $\mathrm{k}$ jejich redukci spojené $\mathrm{s}$ vidinou finančních úspor, přičemž výsledky studie ${ }^{24}$ „Vliv finanční krize na HR v České republice“ poukazují na redukci nabídky benefitů, jež nastala u 1/6 respondentů z oslovených 239 společností. Management podniků část benefitů ponechal beze změny, ${ }^{25} \mathrm{u}$ jiných přistoupili zaměstnavatelé $\mathrm{k}$ omezení či zaměstnaneckou výhodu úplně zrušili. Za této situace bylo však zásadní, zda podnikový management provádí tato úsporná opatření racionálně, a tudíž mimo jiné na základě aktuálních preferencí a požadavků svých zaměstnanců.

\subsection{Budoucnost benefitního odměňování}

Je otázkou, jak uvádí autoři prŕíspěvku, nakolik budou trendy v oblasti zaměstnaneckých benefitư $^{26} \mathrm{v}$ následujících letech ovlivněny legislativními změnami a jakou roli bude benefitní odměňování, jakožto jeden z elementů mzdy pracovníka, zastávat. Jeden z názorů (a možných scénářru), dle Palaty, poukazuje na situaci, že bude-li směřovat vývoj v legislativní a daňové oblasti upravující podmínky poskytování (čerpání) benefitů tzv. „slovenskou“ cestou a dojdeli ke zrušení prakticky veškerých daňových i pojistných výhod benefitů, může nastat situace, kdy bude postupně docházet $\mathrm{k}$ přesunu finančních prostředků určených na benefitní položky do jiné mzdové složky, a to z důvodu pozbytí výhodnosti benefity poskytovat. Již po delší čas se vede polemika nad tím, v horizontu kolika let by mohlo (mělo) dojít ke sjednocení podmínek, resp. k zatížení jednotlivých benefitů vyššími (než v současnosti stanovenými) odvody. Tudíž se z určitého pohledu dostáváme (v případě navýšení odvodové povinnosti) do situace, kdy může být řada benefitů postavena do pozice určité podobnosti s odměnami, jakožto částí variabilní složky mzdy pracovníka. Tento scénář není jediným. Odlišné názory naopak přikládají systému benefitního odměňování značný význam, kdy je vhodné benefity jako nepostradatelný element odměňování prosazovat a zachovat jejich zvýhodněné odvodové povinnostmi, jakožto součást sociální politiky podniku a realizované péče o zaměstnance.

Z tendencí západoevropských společností a především jimi uplatňované struktury benefitů lze soudit, že zvyšující se důraz managementu podniků na prosazování podnikové kultury je orientován nejen do povědomí zaměstnanců. Vyvstává snaha o posílení konkurenceschopnosti podniku a pozitivního vnímání zaměstnavatele jeho zaměstnanci. Dle Urbana lze očekávat, že do budoucna bude vedení podniků směrovat nabídku benefitů do oblasti pracovníky stále více oblíbených zážitkových benefitů. Ty mají často spojitost s adrenalinovým prožitkem jako např́iklad seskok padákem, projížd'ka na raftu, či naopak poklidným prožitkem v podobě víkendového wellness pobytu. Zážitkové benefity prožitou situací posilují „pouto“ mezi zaměstnancem a zaměstnavatelem. Za oblíbené zaměstnanecké výhody je možno považovat také ty, jež jsou poskytovány z povahy podnikatelské činnosti (u bankovních institucí se jedná o vedení účtu zdarma, výhodnější úrokové sazby u poskytovaných úvěrů atd.). ${ }^{27}$

\footnotetext{
${ }^{24}$ LUPTÁKOVÁ, L. Vliv finanční krize na HR v České republice [online]. Hewitt Associates, 2009.

${ }^{25}$ Některé z benefitů (především u společností se zahraniční účastí) zůstaly zachovány v nezměněné podobě, a to i z toho důvodu, že jejich poskytování se odvíjelo od globální strategie vycházející z mateřské společnosti.

${ }^{26}$ PELC, V. Zaměstnanecké benefity v roce 2011. 2011, s. 8. Z pohledu daňově legislativního „zákon o daních z přjimů především vymezuje výdaje (náklady) na dosažení, zajištění a udržení zdanitelných přímů jejich legální definicí; na benefitní plnění se toto obecné vymezení daňových výdajů nevztahuje. Znamená to, že zaměstnavatel musí posoudit, zda plnění, které chce zaměstnanci̊m poskytnout, je plněním benefitním (= není mzdou, není její náhradou, nesouvisí s konkrétním pracovním výkonem zaměstnance, souvisí pouze s existencí závislé činnosti zaméstnance), nebo plněním souvisejicím s výkonem práce, “

${ }^{27}$ URBAN, J. Jak se vyvíjí odméňování ve světě? HRM - Human Resources Management, záŕí - říjen 2011, s. 34.
} 


\subsection{Automatické přidělování benefitů vs. stanovení kritérií}

Dle autorů tohoto článku je žádoucí postoupit bádání v předmětné problematice - analyzovat, do jaké míry je kýžené a racionální, či vůbec lze realizovat smysluplnou sociální politiku v podniku mnohdy podpořenou mimo jiné obsáhlým (finančně nákladným) portfoliem rozličných zaměstnaneckých benefitů při vědomí současného vývoje na trzích. A to za ne moc příznivé predikce vývoje světového hospodářství, za situace neustálého tlaku a sílící konkurence na trzích jak domácích tak i zahraničních. Je patrné, že obsáhlým portfoliem výhod zaměstnavatelé zvyšují svou atraktivitu ve vztahu ke svým zaměstnancům i potenciálním uchazečům o volná pracovní místa a současně jejich vstřícné kroky mohou mít pozitivní dopady na míru fluktuace pracovníků v podniku. Je však třeba, jak uvádí autoři, mít na paměti fakt, že vlivnou sociální politikou (o to více umocněnou v řadě podniků faktem, že jsou benefity čerpány na základě plošného poskytování) zaměstnavatelé „posiluji $u$ zaměstnancủ mentalitu nárokování bez ohledu na jejich skutečný př́nos k výsledkům organizace “, ${ }^{28}$ a to i za situace, kdy čerpání řady zaměstnaneckých výhod není pracovníkem automaticky (ze zákona) nárokovatelné a jejich poskytování závisí na postoji konkrétního zaměstnavatele, resp. na realizované personální politice společnosti. Wagner pak dodává dílčí pohled na systém odměňování ve smyslu takovém, že jsou-li mzdové formy závislé na ukazatelích, které jsou zaměstnanci neovlivnitelné (např. na hospodářském výsledku), ztrácejí motivační účinek. ${ }^{29}$ Realizované výzkumy a uveřejněné studie $\mathrm{z}$ oblasti zaměstnaneckých výhod $^{30}$ poukazují ve většině případů především na to, do jaké míry jsou jednotlivé benefity u zaměstnanců oblíbené či neoblíbené, zda došlo v uplynulém období ze strany zaměstnanců k poklesu či vzestupu zájmu o dané benefitní položky, či se výzkumy zaměřují na rozsah portfolia benefitů vymezeného podnikem - resp. zda došlo k rozšîrenéí či redukci nabídky benefitů (vyplývající z požadavku managementu podniku na snížení finančních nákladů v personální oblasti). Z pohledu analyzování, zda jsou finanční prostředky v podnicích vynakládány (investovány) v oblasti zaměstnaneckých výhod racionálně či nikoliv, do jaké míry jsou benefity přijímány zaměstnanci za běžnou - automatickou, či dokonce rutinní součást formy odměňování, se ve výzkumech setkáváme jen ojediněle. Stejně jako s výzkumnou problematikou, do jaké míry je současná podoba (způsob) poskytování zaměstnaneckých benefitů žádoucí, transparentní a motivující.

I na základě výše uváděných predikcí a možných tendencí budoucího vývoje benefitního odměňování je z pohledu zaměstnavatele žádoucí, aby byla v podnicích mezi pracovníky realizována relevantní výzkumná šetření podpořená podrobnými analýzami, jelikož především na základě znalosti preferencí jednotlivých zaměstnanců může být dosaženo v daném podniku pozitivních posunů co do míry racionální alokace finančních zdrojů a investic do systému benefitního odměňování (resp. portfolia nabízených benefitních položek). Výhody nesmí být pracovníkem přijímány automaticky a jen na základě toho, ,že jsou jedinci nabízeny“. Pracovník v mnoha př́padech benefity nebere jako „něco navíc“, nevnímá je jako nenárokovou složku mzdy, ale jako zažitou samozřejmost, něco automatického až rutinního, a

\footnotetext{
${ }^{28}$ DVOŘÁKOVÁ, Z. a kol. Management lidských zdrojů. 2007, s. 338.

${ }^{29}$ WAGNER, J. Měrení výkonnosti - jak měrit, vyhodnocovat a využívat informace o podnikové výkonnosti. 2009 , s. 143.

${ }^{30}$ Viz závěry studií: BĚŤÁK, J. Employee Benefits 2011 - Zaměstnanecké výhody v mírně rostoucí ekonomice. ING Pojištovna, 2011; či studie společnosti Hewitt Associates. LUPTÁKOVÁ, L. Vliv finanční krize na HR v České republice [online]. Hewitt Associates, 2009; případně studie Salary \& Benefits Guide 2010 - 2011 [online] vycházející z výzkumu realizovaného společností Robert Half International v období 16. 9. - 16. 12. 2010 na téměř 2000 respondentech; či výzkum Slezské univerzity v Opavě s názvem „Péče o zaměstnance jako součást vnitropodnikové sociální politiky v Moravskoslezském kraji“ realizovaný v průběhu roku 2010 - viz KOLIBOVÁ, H. Péče o zaměstnance v programech vnitropodnikové sociální politiky v Moravskoslezském kraji.
} 
to není zajisté záměrem a snahou zaměstnavatele a ve své podstatě ani pracovníka, pro něhož mnohdy čerpání poskytovaných výhod nemá ani zásadní význam a smysl.

\subsection{Realizovaný pilotní průzkum v rámci zpracování tezí disertační práce}

Autoři příspěvku se setkali při studiu odborné literatury a dalších dokumentů pojednávajících o předmětné problematice benefitního odměňování (úzce provázané s hodnocením a odměňováním pracovníků $\mathrm{v}$ podnicích) $\mathrm{s}$ růžnými názory a pohledy na tuto oblast (at' už u domácích či zahraničních autorů), přičemž shledávají za opodstatněné, věnovat se hodnocení a odměňování pracovníků v rámci zpracování disertační práce, a to $\mathrm{s}$ cílem vymezit a porovnat hlavní teoretické a metodické přístupy v oblasti hodnocení a odměňování pracovníků s důrazem na benefitní odměňování; zjistit, jakou roli benefitní odměňování v současnosti v podnicích sehrává, jakožto jeden z elementů v procesu odměňování a navrhnout metodiku benefitního odměňování pracovníka zohledňující pracovníkův postoj k práci ${ }^{31}$. Je dlužno konstatovat, že identifikace přístupů (postojů a vnímání), role, významu benefitního odměňování (a to z pozice představitelů vrcholového managementu vybraných podniků), které v současnosti v procesech hodnocení a odměňování sehrává; stejně jako predikce vývoje do několika dalších let, včetně návrhu metodiky benefitního odměňování pracovníka zohledňující pracovníkův postoj k práci, ${ }^{32}$ je možné jak z teoretické, tak praktické roviny považovat za obohacující a prrínosné nejen pro privátní sféru obecně, ale v bližších souvislostech pak také pro představitele středních a velkých podniků zaměřených na výrobní činnost a podniků poskytujících svým odběratelům primárně služby.

Jak již samotná data získaná v rámci pilotního šetření mezi podniky Moravskoslezského a Zlínského kraje naznačila, je vhodné podstoupit oblast benefitního odměňování bádání co do podmínění čerpání zaměstnaneckých výhod (resp. některých z nich - dle povahy benefitu) splněním managementem stanovených kritérií pro pracovníka, které by zohledňovaly pracovníkův postoj $\mathrm{k}$ práci, především s ohledem na specifikaci pracovního místa a odvětví činnosti podniku. Je možno usuzovat, že stanovená kritéria by podmiňovala ty benefity, jež vzhledem ke své povaze mohou být poskytovány formou flexibilního (individuálního) přístupu a ve své podstatě netvoří skladbu benefitů zajišt'ujících určitý stupeň sociální odpovědnosti podniku vůči svým pracovníkům, resp. nejednalo by se o benefity, u nichž je předpokladem, že budou poskytovány plošně z podstaty jejich charakteru a účelu, jakožto benefity sociální povahy. Stanovená kritéria (zohledňující a reflektující mimo jiné povahu dané pracovní pozice, kterou pracovník zastává a povahu činnosti podniku), v rámci samotného pilotního šetření v dotazníku uváděná, by zohledňovala pracovníkủv postoj k práci a u vybraných benefitních položek by jejich ne/plnění mělo vliv na hodnotovou výši poskytovaného benefitu, jakožto „pojítko, mezistupeň“ zohledňující zaujímaný postoj pracovníka k práci v součinnosti s aktuálně (v odborné literatuře) definovanou podstatou zaměstnaneckých benefitů. Doktorand zastává názor, že podmínění čerpání vybraných benefitů může mít za výsledek pozitivní vliv jak na pracovníka, jeho loajalitu a zainteresovanost pro podnik, samotný přístup k čerpání benefitů, míru významnosti této

\footnotetext{
${ }^{31}$ Postojem k práci (definovaným $\mathrm{v}$ tezích spoluautora článku) se rozumí míra plnění managementem stanovených doprovodných kritérií hodnocení zohledňujících jednotlivé elementy pracovního přístupu pracovníka - jako je: technická zručnost pracovníka; dodržování norem ISO 9001, parametrů jednotného systému ochrany životního prostředí dle ČSN EN ISO 14001; šetrnost při užívání nástrojů při výkonu práce; plnění pokynů nadřízeného pracovníka; kvalita odvedené práce; míra absence v docházce pracovníka do práce; příp. jiných stanovených kritérií.

32 Je patrné, že tvorba nové ,metodiky benefitního odměňování pracovníka zohledňující pracovníkův postoj k práci“ by vyžadovala dílčí úpravy př́slušné legislativy a vytýčení skupiny benefitů dle určitých specifik, na něž by se kritéria zohledňující postoj pracovníka k práci uplatňovala.
} 
složky mzdy pracovníka, tak pro zaměstnavatele ve vztahu k racionální alokaci finančních prostředků, které do oblasti benefitního odměňování plynou. ${ }^{33}$

Dotazník, ${ }^{34}$ jež bude respondentům předkládán v rámci výzkumu v disertační práci, obsahuje otázky týkající se: aktuálního postoje managementu podnikủ k hodnocení a odměňování pracovníků ve vztahu k benefitnímu odměňování; míry významnosti benefitního odměňování (jeho roli a pozici) v podnicích; predikce následného vývoje v této oblasti odměňování z pohledu představitelů managementu podniků. Data získaná šetřením na předpokládaném vzorku 1500 - 2000 respondentů (středních a velkých podniků působících na území ČR) a závěry z nich odvozené budou východiskem pro naplnění jednoho ze dvou dílčích cílů práce v součinnosti s vymezením hlavního cíle disertační práce. Konkrétně budou výzkumným šetřením zajištěna data ${ }^{35}$ (sběr dat), přičemž na základě následně provedených analýz a vyhodnocení budou stanoveny závěry, které umožní odpovědět na souvislosti vztahující se k problematice vyjádřené ve třech hypotézách disertační práce.

Hypotéza č. 1: Lze předpokládat, že př́istup managementu podniků k odměňování pracovníků, především k benefitnímu odměňování, má vliv na postoj pracovníka k odváděné práci.

Hypotéza č. 2: Je možno usuzovat, že benefitnímu odměňování pracovníků není managementtem podniků přikládána dostatečná významnost ve vztahu k ostatním elementům odměňování.

Hypotéza č. 3: Lze předpokládat, že management podniků nebude mít zájem v následujících letech na zvyšování podílu benefitního odměňování, co do významnosti tohoto elementu $\mathrm{v}$ rámci odměňování pracovníků.

Samotný dotazník, předkládaný respondentům v druhé dekádě února 2012 v rámci pilotního šetření při vypracovávání tezí disertační práce, obsahuje celkem 28 otázek korespondujících se stanovenými hypotézami, přičemž jsou v něm uvedeny otázky související s následujícím:

- zda se jedná o společnost mateřskou či dceřinou; s jakou specifikací činnosti v rámci odvětví výroby a služeb ${ }^{36}$; zda jde o tuzemský či zahraniční podnik a co do počtu zaměstnanců zda jde o střední či velký podnik;

- zda odměňování pracovníkova výkonu má vliv na jeho výkon; zda hodnocení pracovníků v podnicích koresponduje se skutečně odvedeným výkonem pracovníků za sledované období; - jaká míra důležitosti $\mathrm{v}$ podnicích je $\mathrm{v}$ současné době přikládána potřebě vzájemné provázanosti hodnocení pracovníka a odměňování pracovníka; hodnocení pracovníka a benefitního odměňování pracovníka;

- zda benefitní odměňování pracovníka má vliv (a případně jak značný) na pracovníkův postoj k práci; jakou váhu představitelé managementu podniků prrikládají benefitnímu

\footnotetext{
${ }^{33}$ Problematice stanovení kritérií hodnocení a odměňování zohledňujících „pracovníkův postoj k práci“ se věnuje taktéž článek Ing. Řiháka: Návrh dílčí koncepce systému benefitního odměňování zaměstnanců ve výrobním podniku na principech cafeteria systému. In Acta academica karviniensia, 3/2011. Karviná : SU OPF, 2011, s. 112 - 124. ISSN 1212-415X.

${ }^{34}$ Dotazník předkládaný v rámci pilotního šetření je přílohou (Př́iloha 1) tezí disertační práce Ing. Řiháka.

${ }^{35} \mathrm{~V}$ dotazníku jsou nejčastěji využity otázky mající podobu uzavřených otázek s variantně pevně stanovenými možnostmi odpovědí; případně otázky s možností odpovědí, kde může respondent vyjádřit svůj názor (postoj) označením (volbou) i více možností současně. Dotazník obsahuje několik polouzavřených otázek, v nichž může oslovený vybírat z nabídky uvedených odpovědí, přičemž má možnost dopsat také svou vlastní odpověd', jakožto jednu z variant projevení názoru. Své opodstatnění mají v předkládaném dotazníku také dichotomické otázky, at' už otevřené či uzavřené.

${ }^{36}$ V rámci výzkumného šetření budou respondenti členěni co do odvětvové činnosti na: hutnický průmysl; strojírenský průmysl; automobilový průmysl; elektrotechnický průmysl; či jiná (v tomto výčtu nespecifikovaná činnost z oblasti výroby v rámci zpracovatelského průmyslu); př́ípadně zda se jedná o podnik ze sektoru služeb zaměřující se primárně na: dopravu; ubytování; stravování, pohostinství; kulturní, zábavní a rekreační činnosti; peněžnictví a pojištovnictví; jinou (v tomto výčtu nespecifikovanou oblast sektoru služeb).
} 
odměňování ve vztahu k utváření podnikové kultury v podnicích a miřre účelnosti vynakládání finančních prostředků na zaměstnanecké benefity;

- zda a jaká míra významnosti je benefitnímu odměňování v podnicích přikládána ve vztahu k ostatním složkám odměňování; zda (a případně na základě jakých skutečností) je čerpání zaměstnaneckých výhod pracovníkem v podnicích podmíněno splněním určitých podmínek pro jejich čerpání;

- zda v nadcházejících letech představitelé managementu podniků plánují podmínit pracovníkovi čerpání flexibilně poskytovaných benefitů nutností splnění určitých kritérií zohledňujících pracovníkův postoj k práci;

- jaký přístup (formu) poskytování zaměstnaneckých výhod pracovníkovi je praktikován v podnicích; na základě jakých vlivů došlo ke změnám (rozšíření, stagnaci či redukci) portfolia benefitů za specifikované období; zda a jaký podíl v současnosti představuje (a do budoucna je predikován) benefitní odměňování na celkové mzdě pracovníka.

$\mathrm{V}$ rámci průzkumu byl dotazník předložen dvěma respondentům z řad středních a velkých podniků se sídlem ve Zlínském kraji, přičemž jeden z podniků je střední velikosti co do počtu zaměstnanců, v odvětví činnosti - výroba (strojírenský průmysl). U druhého z oslovených se jedná také o podnik střední velikosti, v odvětví činnosti - poskytování služeb. V Moravskoslezském kraji pak byly osloveny dva velké podniky, co do počtu zaměstnanců, jejichž odvětvím činnosti je v obou prrípadech výroba - strojírenský průmysl. Realizované pilotní šetření umožnilo především v rámci oslovení čtyř respondentů ověřit vhodnost v dotazníku uvedených otázek, z pohledu správnosti po obsahové a stylistické stránce, jednoznačnosti jejich pochopení a správného vyplnění dle uvedených pokynů, přičemž poskytnul taktéž poznatky, které byly posléze zapracovány do aktuální podoby dotazníku. Průzkum poukázal na oprávněnost položených otázek, co do jejich tematického směřování, kdy bylo možno vysledovat u všech čtyř respondentů jednotný názor, a sice že benefitnímu odměňování je podniky přikládána „částečná významnost“ ve vztahu k ostatním složkám odměňování. Ve všech prrípadech respondenti odpověděli souhlasně také u otázky týkající se účelu poskytování zaměstnaneckých benefitů, kdy všichni oslovení se vyjádřili, že benefity „,̌ástečně plní svůj účel, jsou pro pracovníka dílčím př́ínosem, mají pozitivní vliv na jeho loajalitu vůči společnosti, je však třeba se zaměřit ve vyšší míře na individuální prŕístup ke každému z pracovníků při poskytování benefitů“. Mimo jiné u $75 \%$ oslovených je možno konstatovat, že mají zájem na tom a „považuji za vhodné, aby byly při poskytování některých benefitů kladeny požadavky na splnění kritérií zohledňující pracovníkův postoj $\mathrm{k}$ práci, umožňující následně managementu diferencovat pracovníky podle míry splnění stanovených kritérií a také rozlišit výši hodnoty benefitu přidělovanou každému z nich, neposkytovat tedy benefit pouze za to, že pracovník v podniku působí několik let“. Tento fakt vyplývající jakožto jeden ze stěžejních závěrů byt' setření pilotního charakteru, je možno považovat za podtrhnutí významnosti doktorandem zkoumané problematiky, resp. zájem o posun v oblasti benefitního odměňování co do adekvátní potřeby podmínit poskytování benefitů pracovníkovi požadavkem na splnění stanovených kritérií zohledňujících jeho postoj k práci.

Pilotáž také poukázala na oprávněnost položených otázek, co do jejich souslednosti. V předvýzkumu všichni oslovení respondenti odpověděli vyčerpávajícím způsobem na $96 \%$ otázek. Nedošlo tedy $\mathrm{k}$ případnému nezodpovězení některé $\mathrm{z}$ otázek $\mathrm{z}$ důvodu pozbytí návaznosti, resp. nepochopení jejich obsahu, či dopsání poznámky, upozorňující na fakt nesrozumitelnosti. Dílčí nejasnost bylo možno vysledovat u jedné otázky (4\%) obsahující výčet jednotlivých forem Cafeteria systému s tím, že byl dvěma respondenty uveden požadavek na bližší specifikaci tohoto termínu, resp. jednotlivých forem systému. Na základě tohoto požadavku tazatel jednotlivé možnosti odpovědi doplnil o vysvětlující text vztahující se k jednotlivým formám Cafeteria systému. 
Závěry pilotního šetření, které obecně ze své podstaty neslouží primárně k detailnímu analyzování dat a podrobné specifikaci jednotlivých zvolených odpovědí, ale jeho významové hledisko spočívá především v ověření vypovídací schopnosti co do pochopení otázek a stylistické správnosti textu, tak naznačilo pozitivní přístup respondentů k předmětné problematice a vhodné směřování výzkumného záměru jak z pohledu obsahového tak stylistického.

\section{Závěr}

Dopady hospodářského útlumu (především v letech 2008 až 2010) zapř́ičinily v oblasti podnikového řízení lidských zdrojů podstatné změny, a to především v procesech hodnocení a odměňování pracovníků. Také v těchto souvislostech autoři předkládaného článku poukazují na důležitost a významnost propojení procesů hodnocení a odměňování pracovníků, včetně systému benefitního odměňování, uplatňovaných v jednotlivých podnicích, přičemž důraz na vyváženost sociální politiky podniku, co do portfolia poskytovaných služeb pro zaměstnance, je předpokladem $\mathrm{k}$ vytváření příznivého pracovního prostředí a pozitivních vzájemných vztahů na pracovišti, jež mají vliv na míru angažovanosti a loajality pracovníka a v neposlední řadě dopad na jím zaujímaný postoj k práci. Perspektivní - nerutinní - poskytování zaměstnaneckých benefitů a racionální alokace finančních zdrojů je dle autorů článku nezbytným předpokladem nejen v oblasti sociální politiky každého podniku.

Jak výsledky předvýzkumu realizovaného v rámci zpracovávání tezí disertační práce doktoranda prokázaly, je vhodné do budoucna diferencovat (v rámci benefitního odměňování) pracovníky podmíněním splnit managementem stanovená kritéria u určených benefitů pro umožnění jejich následného čerpání. Zároveň pilotáž prokázala zájem zaměstnavatelů (respondentů) o zkoumanou a autory článku řešenou problematiku - tedy opodstatněnost a racionalitu v jimi prezentovaných záměrech.

\section{Literatura:}

[1] ARMSTRONG, M. Řízení lidských zdrojů. 8. vyd. Praha: Grada Publishing, 2002, 856 s. ISBN 80-247-0469-2.

[2] DVOŘÁKOVÁ, Z. a kol. Management lidských zdrojů. 1. vyd. Praha: C. H. Beck, 2007, 485 s. ISBN 978-80-7179-893-4.

[3] HRONÍK, F. Hodnocení pracovníkio. 1. vyd. Praha: Grada Publishing, 2006, 128 s. ISBN 80-247-1458-2.

[4] KOLIBOVÁ, H. a kol. Péče o zaměstnance v programech vnitropodnikové sociální politiky v Moravskoslezském kraji. 1. vyd. Opava: Slezská univerzita, 2010, 438 s. ISBN 978-80-7248-611-3.

[5] LUPTÁKOVÁ, L. Vliv finanční krize na HR v České republice [online]. Hewitt Associates, 2009. URL:<http://www.peoplemanagementforum.cz/data/file/ostatni/ Vlivfinancni_krize_na_HR_v_Ceske_republice.pdf.>, [cit. 2011-09-18].

[6] PALATA, K. Trendy v odměňování. HRM - Human Resources Management, březen duben 2011, roč. 7, č. 2, s. 12 - 15. ISSN 1801-4690.

[7] PELC, V. Zaměstnanecké benefity v roce 2011. Praha : Leges, 2011, 240 s. ISBN 97880-87212-66-0.

[8] PILǍ̌OVÁ, I. Jak efektivně hodnotit zaměstnance a zvyšovat jejich výkonnost. 1. vyd. Praha: Grada Publishing, 2008, 128 s. ISBN 978-80-247-2042-5.

[9] ̌IIHÁK, R. Odměňování pracovníků ve středních a velkých podnicích. Teze disertační práce. Karviná: SU OPF, 2012, 32 s.

[10] TOMEŠ, I. Sociální politika: teorie a mezinárodní zkušenost. 1. vyd. Praha: Sociopress, 1996, 213 s. ISBN 80-902260-0-0. 
[11] URBAN, J. Jak se vyvíjí odměňování ve světě? HRM - Human Resources Management, září - ř́íjen 2011, roč. 7, č. 5, s. 34 - 36. ISSN1801-4690.

[12] VODÁK, J., KUCHARČÍKOVÁ, A. Efektivní vzdělávání zaměstnanců. 2. vyd. Praha: Grada Publishing, 2011, 240 s. ISBN 978-80-247-3651-8.

[13] WAGNER, J. Měrení výkonnosti - jak měřit, vyhodnocovat a využívat informace o podnikové výkonnosti. 1. vyd. Praha: Grada Publishing, 2009, 248 s. ISBN 978-80-2472924-4.

\section{JEL J32, M12}

Ing. Radim Řihák, doc. RSDr. Vojtěch Malátek, CSc.

Slezská univerzita v Opavě

Obchodně podnikatelská fakulta v Karviné

Katedra společenských věd

Univerzitní nám. 1934/3

73340 Karviná

rihak.r@seznam.cz

malatek@opf.slu.cz 